\title{
Patient and Economic Burden of Presbyopia: A Systematic Literature Review
}

This article was published in the following Dove Press journal:

Clinical Ophthalmology

\author{
John Berdahl (D)' \\ Chandra Bala $\mathbb{D}^{2}$ \\ Mukesh Dhariwal (iD ${ }^{3}$ \\ Jessie Lemp-Hull ${ }^{4}$ \\ Divyesh Thakker ID $^{5}$ \\ Shantanu Jawla $\mathbb{D}^{5}$
}

'Vance Thompson Vision, Sioux Falls, SD, USA; ${ }^{2}$ Faculty of Medicine and Health Sciences, Macquarie University, Sydney, New South Wales, Australia; ${ }^{3}$ Global Health Economics \& Outcomes Research, Alcon Vision LLC, Fort Worth, TX, USA; ${ }^{4}$ Clinical Development and Medical Affairs, Alcon Vision LLC, Fort Worth, TX, USA; ${ }^{5}$ Patient Access Services, Novartis Healthcare Pvt Ltd., Hyderabad, Telangana, India
Correspondence: Dr Mukesh Dhariwal Alcon Vision LLC, 620I South Freeway, TA3-8, Fort Worth, TX 76134-2099, USA $\mathrm{Tel}+\mid 8173631577$

Fax +I 8008625266

Email mukesh.dhariwal@alcon.com
Purpose: The objective of this systematic literature review (SLR) was to collate, report, and critique published evidence related to epidemiology and patient and economic burden of presbyopia.

Patients and Methods: A systematic literature search was conducted in $\operatorname{MEDLINE}^{\circledR}$, Embase $^{\circledR}$, and Cochrane Library databases from the time of inception through October 2018 using Cochrane methodology. Studies published in English language reporting on epidemiology and patient and economic burden of presbyopia were included.

Results: Initial systematic literature search yielded 2,228 citations, of which 55 met the inclusion criteria (epidemiology, 44; patient burden, 14; economic burden, 1) and were included in this review. Globally, 1.09 billion people are estimated to be affected by presbyopia. The reported presbyopia prevalence varied across regions and by age groups, with the highest prevalence of $90 \%$ reported in the Latin America region in adults $\geq 35$ years. Presbyopic patients report up to $22 \%$ decrease in quality-of-life (QoL) score, and up to $80 \%$ patients with uncorrected presbyopia report difficulty in performing near-vision related tasks. About $12 \%$ of presbyopes required help in performing routine activities, and these visual limitations reportedly induce distress and low self-esteem in presbyopia patients. Uncorrected presbyopia led to a 2-fold increased difficulty in near-vision-related tasks and a $>8$-fold increased difficulty in very demanding near-vision-related tasks. Further, uncorrected presbyopia leads to a decrement in patients' QoL, evident by the low utility values reported in the literature. Annual global productivity losses due to uncorrected and undercorrected presbyopia in working-age population ( $<50$ years) were estimated at US\$ 11 billion $(0.016 \%$ of the global domestic product (GDP) in 2011, which increased to US\$ 25.4 billion if all people aged $<65$ years were assumed to be productive.

Conclusion: Uncorrected presbyopia affects patients' vision-related quality of life due to difficulty in performing near-vision-related tasks. In addition, un-/under-corrected presbyopia could lead to productivity losses in working-age adults.

Keywords: presbyopia, burden of disease, quality of life, productivity loss, patient satisfaction, utilities

\section{Introduction}

Presbyopia is an age-related impairment of near-vision characterized by gradual decrease in accommodation of the eye. It stems from a gradual thickening and loss of viscoelasticity of the natural lens. ${ }^{1,2}$ The loss of lens elasticity may be attributed to oxidized protein sulphydryl groups within lens fiber cells from intraprotein crosslinks that, with time, leads to loss of accommodative amplitude. ${ }^{2}$ Blurred vision and inability to see clear details at the near working distance are the hallmarks of presbyopia. $^{3}$ 
Presbyopia starts to become functionally apparent around 40 years and affects individuals for a considerable part of their working life. ${ }^{4}$ If left uncorrected or under-corrected, presbyopia could result in potential productivity losses. ${ }^{5}$ The usage of digital devices is increasing significantly for both social and professional purposes, and leads to eye strain or vision stress. The adoption of digital technology has made better near vision a necessity due to exponential increase in the use of screens for work and leisure. ${ }^{6}$ Presbyopic subjects suffer from additional visual stress and productivity losses due to age-related loss of accommodation, as their intermediate and near vision (needed for viewing digital devices) is often left under-/un-corrected. ${ }^{7,8}$

Presbyopia is near universal in older patients presenting for cataract surgery. In cataract patients undergoing surgery, removal of the cataractous lens and implantation with an artificial intraocular lens (IOL) leads to total loss of accommodation, resulting in postoperative presbyopia. Implantation of standard monofocal IOLs (usually reimbursed under covered benefit) corrects only distance vision without near and intermediate vision correction. Uncorrected post-operative presbyopia still remains a challenge for patients, ophthalmologists, and optometrists. 9

The objective of this systematic literature review (SLR) was to collate and report evidence related to the epidemiology and patient and economic burden of presbyopia alone or when coexisting with other eye conditions.

\section{Materials and Methods}

This SLR was conducted in accordance with the standard systematic review methodology endorsed by the Cochrane Collaboration. ${ }^{10}$ The findings from this SLR are reported in accordance with the Preferred Reporting Items for Systematic Reviews and Meta-Analyses (PRISMA) guidelines. ${ }^{11}$

The systematic literature searches were conducted in the Embase ${ }^{\circledR}$, MEDLINE $^{\circledR}$, and Cochrane Library medical literature databases from the time of database inception through October 26, 2018. The key search terms for retrieving studies of interest were presbyopia, epidemiology ("incidence," "prevalence,"), patient burden ("patient reported outcome," "quality of life," "health related quality of life," "activities of daily living," etc.), and economic burden ("direct cost," "indirect cost," "productivity loss," "resource use," etc.). The search was restricted to articles published in English language.
Additionally, abstracts presented at keyophthalmology congresses for the past 3 years (2015 to 2018) were hand searched to retrieve either recentstudies that had not yet been published in journals as full-text articles or supplement results of previously published studies (Supplementary Material Table S1).

Following the search process, titles and abstracts of all retrieved citations were screened according to the predefined eligibility criteria (Table 1). Following the initial screening, potentially relevant or unclear citations were identified for full-text evaluation. The study selection process was performed by two independent reviewers, with any discrepancies between reviewers reconciled by a third independent reviewer. Data related to study characteristics and disease burden were extracted into a specifically designed data extraction grid in Microsoft Excel (Microsoft Corporation, USA). The data were extracted by a single independent reviewer and checked for accuracy by a second independent reviewer. Multiple publications of the same study were linked and considered as a single study while extracting relevant data.

\section{Results}

The PRISMA flow diagram summarizing the process and findings of the systematic literature search is presented in Figure 1.

The literature search yielded 2,228 citations, of which 391 duplicates were removed. Based on the predefined inclusion and exclusion criteria, the titles and abstracts of all the unique 1,837 citations obtained were screened. Following the first screening of the citations, 334 potentially relevant references were identified for full-text evaluation. After linking multiple publications for the same study, 53 studies from 55 publications were included for data extraction, of which 43 studies reported data on epidemiology, 12 studies reported data on patient burden, and one study reported data on economic burden. As some of the studies evaluated multiple objectives, there was an overlap among the studies. Two of the included studies were systematic reviews. For brevity, only the characteristics of studies for patient burden and economic burden are described in Table 2.

\section{Epidemiology}

In the 43 included studies reporting on epidemiology, 34 studies used a broadly similar definition for the diagnosis of presbyopia. Presbyopia was defined either as "near vision $\mathrm{N} 8$ or less" ( $\mathrm{N}=24$ studies) or near vision worse than $6 / 12$ or $20 / 40$ at $40 \mathrm{~cm}(\mathrm{~N}=4$ studies $)$ or as: 
Table I Inclusion and Exclusion Criteria

\begin{tabular}{|c|c|c|}
\hline & Inclusion Criteria & Exclusion Criteria \\
\hline Population & $\begin{array}{l}\text { - Patients with presbyopia (including presbyopia along with cataract [pre- } \\
\text { operative as well as post-operative]) } \\
\text { - Presbyopia with other refractive errors (eg, astigmatism) } \\
\text { - Age - No restriction }\end{array}$ & $\begin{array}{l}\text { - Patient population other than } \\
\text { presbyopia }\end{array}$ \\
\hline Interventions & - Not applicable & - Not applicable \\
\hline Comparators & - Not applicable & - Not applicable \\
\hline Outcomes & $\begin{array}{l}\text { - Epidemiology } \\
\text { - Prevalence and incidence rates of presbyopia } \\
\text { - Economic burden } \\
\circ \text { Direct and indirect costs of presbyopia correction } \\
\text { - Healthcare resource utilization } \\
\text { - Productivity loss } \\
\text { - Patient burden } \\
\circ \text { Impact on vision-related quality of life } \\
\circ \text { Disability and impact on daily activities } \\
\circ \text { Utility associated with presbyopia } \\
\circ \text { Patient satisfaction }\end{array}$ & $\begin{array}{l}\text { - Studies not reporting outcomes of } \\
\text { interest }\end{array}$ \\
\hline Study designs & $\begin{array}{l}\text { - RCTs and observational studies } \\
\text { - SLRs }\end{array}$ & $\begin{array}{l}\text { - Reviews/Case-studies/Editorial/Case } \\
\text { reports/Case series }\end{array}$ \\
\hline
\end{tabular}

Abbreviations: RCTs, randomized controlled trial; SLR, systematic literature review.

Needing optical correction added to the presenting distance refractive correction to achieve $\mathrm{a} \geq 1$ line of near visual acuity improvement or, $\mathrm{J} 1$ print or $\mathrm{N} 8$ print. ( $\mathrm{N}=6$ studies) In nine studies, presbyopia definition was not clearly stated (Supplementary Material Table S2).

\section{Prevalence}

The Centers for Disease Control and Prevention (CDC) defines prevalence as "proportion of persons in a population having a disease or attribute at a specified point in time or over a specified time-period and includes both new and pre-existing cases." 12

In 2015, the global prevalence of presbyopia was estimated to be 1.09 billion. ${ }^{13}$ Overall, presbyopia remains widespread across the geographical regions. The reported prevalence ranged from $43.8 \%$ in Japan (age $\geq 40$ years) to $88.9 \%$ (age $\geq 45$ years) in USA. In the identified studies, the highest reported prevalence of presbyopia was $90.0 \%$ (age $\geq 35$ years), in Nicaragua (Latin America). ${ }^{14}$ Other Latin American studies reported presbyopia prevalence rates of $43.6 \%$ in Venezuela, and $54.7 \%$ (age $\geq 30$ years) to $76.0 \%$ (age $\geq 45$ years) in Brazil. ${ }^{15-17}$ In USA, presbyopia prevalence ranged from $83.0 \%$ to $88.9 \%$ for adults aged $\geq 45$ years. $^{15,18}$
In Africa, presbyopia prevalence rates ranged from $25.1 \%$ in Kenya to $89.2 \%$ in Tanzania for adults $\geq 30$ years. ${ }^{15,19-32}$ The substantially lower reported presbyopia prevalence rate of $25.1 \%$ in the study from Kenya could be attributed to diagnostic uncertainty. ${ }^{23}$ Some of the study teams used only torches and direct ophthalmoscopes to examine the study participants, and consequently no detailed diagnoses were possible. ${ }^{23}$ The study in Tanzania ${ }^{25}$ was performed in a nationally representative sample of 400 people aged between 40 and 50 years. However, other details including the definition for presbyopia diagnosis was not provided therefore it is difficult to interpret and contrast substantial differences in estimated presbyopia prevalence rate between these two African countries and data should be interpreted with caution. Future studies in Africa should use standardized diagnosis definition and methods.

In the Asia-Pacific region, reported prevalence of presbyopia varied between countries and age groups. In Pakistan, presbyopia prevalence ranged from $57.5 \%$ to $71.2 \%$ for adults aged $\geq 30$ years. ${ }^{15,33}$ Whereas, for adults aged $\geq 40$ years, the reported prevalence ranged from $43.8 \%$ in Timor-Leste to $67.3 \%$ in the People's Republic of China. ${ }^{15,33-51}$ One study conducted in the urban 


\section{PRISMA FLOW CHART}
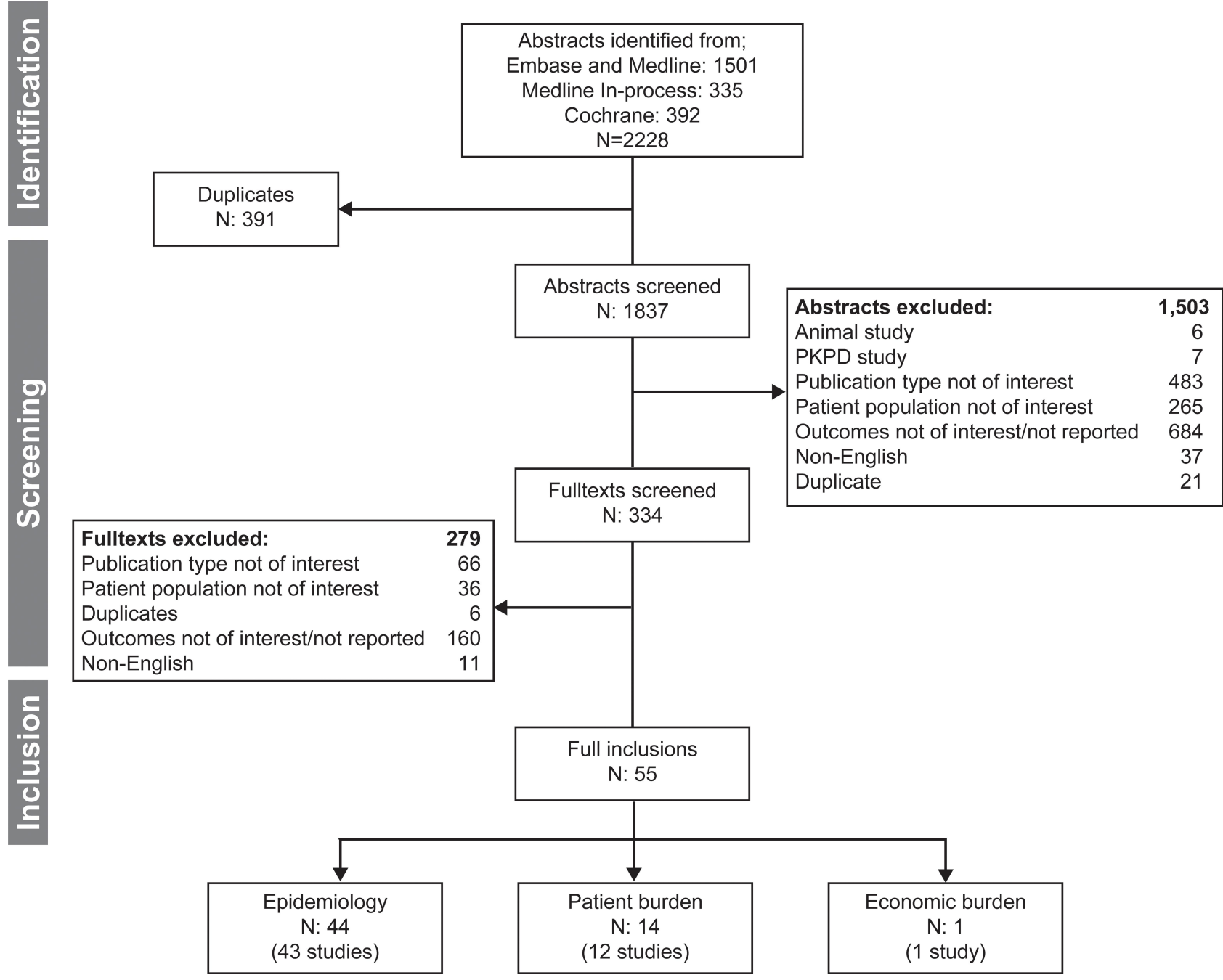

Figure I PRISMA flow chart.

Note: The numbers of studies under different section headings are not exclusive as some studies fall under more than one section.

Abbreviations: N, number of publications; PD, pharmacodynamics; PK, pharmacokinetics.

Chinese population reported presbyopia prevalence rates of $25.2 \%$ for adults aged $\geq 35$ years. ${ }^{52}$ Low prevalence reported in the study as compared to other Asia-Pacific studies was attributed to significant differences in age distributions, socioeconomic status and definitions utilized. ${ }^{52}$ None of the identified studies reported on presbyopia prevalence in the European region.

\section{Incidence}

The Centers for Disease Control and Prevention (CDC) defines incidence as "occurrence of new cases of disease in a population over a specified time-period." $" 12$ The incidence of presbyopia was reported in a population-based study conducted in 1,191 patients aged $\geq 35$ years from aurban district in People's Republic of China in $2008 .^{52}$ The estimated 6-year incidence of presbyopia was $42.8 \%$ (95\% confidence interval [CI]: 39.4-50.1), with older and more hyperopic subjects being at a higher risk of developing presbyopia $(p<0.001){ }^{52}$

\section{Risk Factors}

Among the various risk factors attributed to presbyopia, age plays a significant role. ${ }^{13,53-55}$ With increasing age, the flexibility of the natural eye lens starts decreasing, affecting its ability to accommodate and focus on near objects. ${ }^{35}$ The odds of developing presbyopia increases by $16 \%$ per year from age 40 to 50 (odds ratio [OR]: 1.16; $95 \%$ CI $1.12-1.20$ ), and by just $1 \%$ per year after age 50 (OR: 
Table 2 Characteristics of the Included Studies

\begin{tabular}{|c|c|c|c|c|c|c|c|c|}
\hline $\begin{array}{l}\text { Study } \\
\text { Name }\end{array}$ & Study Design & Country & Setting & Study Period & $\begin{array}{l}\text { Sample } \\
\text { Size }\end{array}$ & $\begin{array}{l}\text { Age, } \\
\text { Mean } \\
\text { (SD) } \\
\text { Years }\end{array}$ & $\begin{array}{l}\text { Female } \\
(\%)\end{array}$ & Outcomes \\
\hline \multicolumn{9}{|c|}{ Patient burden } \\
\hline $\begin{array}{l}\text { Kandel et al } \\
2017^{60}\end{array}$ & $\begin{array}{l}\text { Cross-sectional } \\
\text { study }\end{array}$ & Australia & Multicenter & & 48 & $\begin{array}{l}\text { Median: } 49 \\
\text { (min: } 22 ; \\
\max : 76)\end{array}$ & $59 \%$ & $\begin{array}{l}\text { Impact on daily } \\
\text { activities }\end{array}$ \\
\hline $\begin{array}{l}\text { Luo et al } \\
2008^{65}\end{array}$ & $\begin{array}{l}\text { Cross-sectional } \\
\text { study }\end{array}$ & US & Multicenter & NR & 110 & $59.8(12.2)$ & $71 \%$ & $\begin{array}{l}\text { Utility associated } \\
\text { with corrected } \\
\text { presbyopia }\end{array}$ \\
\hline $\begin{array}{l}\text { Holden et al } \\
2008^{15}\end{array}$ & SLR & Global & NA & 2005 & NA & NA & NA & Disabilities \\
\hline $\begin{array}{l}\text { McDonnell } \\
\text { et al } \\
2004^{58,69}\end{array}$ & $\begin{array}{l}\text { Cross-sectional } \\
\text { study }\end{array}$ & US & Multicenter & $\begin{array}{l}\text { June } 1999 \text { to } \\
\text { January } 2001\end{array}$ & 637 & $\begin{array}{l}\text { Range: } \\
32-56\end{array}$ & $\begin{array}{l}56 \% \text { to } \\
79 \%\end{array}$ & QoL \\
\hline $\begin{array}{l}\text { Tahhan et al } \\
2013^{66}\end{array}$ & $\begin{array}{l}\text { Cross-sectional } \\
\text { study }\end{array}$ & Australia & Multicenter & $\begin{array}{l}\text { July } 2010 \text { to } \\
\text { January } 2012\end{array}$ & 341 & $52(7)$ & $58.10 \%$ & $\begin{array}{l}\text { Utility associated } \\
\text { with uncorrected } \\
\text { presbyopia }\end{array}$ \\
\hline $\begin{array}{l}\text { Kandel et al } \\
2017^{61}\end{array}$ & $\begin{array}{l}\text { Cross-sectional } \\
\text { study }\end{array}$ & Nepal & Multicenter & $\begin{array}{l}\text { September to } \\
\text { November } 2016\end{array}$ & 101 & $34.4(15.1)$ & $45.5 \%$ & $\begin{array}{l}\text { Impact on daily } \\
\text { activities }\end{array}$ \\
\hline $\begin{array}{l}\text { Hatef et al } \\
2016^{63}\end{array}$ & $\begin{array}{l}\text { Secondary } \\
\text { research using } \\
\text { GBD } 2010 \text { study }\end{array}$ & Iran & NA & $1990-2010$ & NA & NA & NA & $\begin{array}{l}\text { Disability adjusted life } \\
\text { years }\end{array}$ \\
\hline $\begin{array}{l}\text { Muhammad } \\
\text { et al } 2015^{57}\end{array}$ & $\begin{array}{l}\text { Cross-sectional } \\
\text { study }\end{array}$ & Nigeria & Multicenter & 2012 & 650 & $\begin{array}{l}53.6(95 \% \\
\mathrm{Cl}: \\
52.8-54.3)\end{array}$ & $39.20 \%$ & $\begin{array}{l}\text { Impact on daily } \\
\text { activities }\end{array}$ \\
\hline $\begin{array}{l}\text { Lu et al } \\
2011^{36,37}\end{array}$ & $\begin{array}{l}\text { Cross-sectional } \\
\text { study }\end{array}$ & China & Multicenter & $\begin{array}{l}\text { June to } \\
\text { July } 2009\end{array}$ & 1008 & $57.5(10.5)$ & $57.50 \%$ & $\begin{array}{l}\text { Impact on daily } \\
\text { activities }\end{array}$ \\
\hline $\begin{array}{l}\text { Toit et al } \\
2010^{59}\end{array}$ & $\begin{array}{l}\text { Cross-sectional } \\
\text { study }\end{array}$ & $\begin{array}{l}\text { Timor- } \\
\text { Leste }\end{array}$ & Multicenter & 2005 & 704 & $58.3(12.8)$ & $49.4 \%$ & $\begin{array}{l}\text { HRQoL, Impact on } \\
\text { daily activities }\end{array}$ \\
\hline $\begin{array}{l}\text { Sherwin } \\
\text { et al } 2008^{28} \\
\text { Patel et al } \\
2007^{21,62}\end{array}$ & $\begin{array}{l}\text { Cross-sectional } \\
\text { study } \\
\text { Cross-sectional } \\
\text { study }\end{array}$ & $\begin{array}{l}\text { Kenya } \\
\text { Tanzania }\end{array}$ & $\begin{array}{l}\text { Multicenter } \\
\text { Multicenter }\end{array}$ & NR & $\begin{array}{l}134 \\
1709\end{array}$ & $\begin{array}{l}65.2(10.3) \\
53.4 \text { (range: } \\
40-91)\end{array}$ & $\begin{array}{l}\text { NR } \\
55.90 \%\end{array}$ & $\begin{array}{l}\text { Impact on daily } \\
\text { activities } \\
\text { Impact on daily } \\
\text { activities }\end{array}$ \\
\hline \multicolumn{9}{|c|}{ Economic burden } \\
\hline $\begin{array}{l}\text { Frick et al } \\
2015^{5}\end{array}$ & $\begin{array}{l}\text { Economic } \\
\text { evaluation }\end{array}$ & Global & NR & 2011 & NR & NR & NR & $\begin{array}{l}\text { Global productivity } \\
\text { loss associated with } \\
\text { presbyopia }\end{array}$ \\
\hline
\end{tabular}

Abbreviations: NA, not applicable; NR, not reported; SD, standard deviation; Cl, confidence interval; US, United States; UK, United Kingdom; GBD, Global Burden of Disease; HRQoL, health-related quality of life.

1.01; 95\% CI 0.99-1.03). ${ }^{22}$ The odds of developing presbyopia increases by approximately 4-7 times in patients with hyperopia and by approximately 2 times in patients with myopia compared to emmetropic subjects. ${ }^{35,38}$
Patients with these refractive errors typically tend to experience the onset of presbyopia earlier than emmetropic subjects. ${ }^{35}$ Women often start wearing spectacles for near-vision at a younger age than men. ${ }^{22,26,38}$ Other factors 
that may contribute to accelerating the progression of presbyopia include certain medical conditions (eg, cardiovascular disease, diabetes mellitus, and multiple sclerosis) and drugs (eg, antihistamines and antidepressants). ${ }^{56}$

\section{Patient Burden}

\section{Impact of Presbyopia on Quality of Life}

Among the included studies for presbyopia, patient burden, outcomes related to quality of life (QoL), and disability in daily activities were reported in 10 studies. Three studies reported the impact of presbyopia on vision-related quality of life. ${ }^{57-59}$ All identified studies were cross-sectional in design. Findings from these studies indicated that uncorrected presbyopia patients had reduced vision-related quality of life.

Muhammad et al (2015) $)^{57}$ conducted a population-based cross-sectional survey to determine the impact of uncorrected presbyopia on vision-related quality of life and visual function (VF) using the 14-item Visual Function Index (VF14) and modified vision-related quality of life questionnaire in Nigerian adults aged $\geq 40$ years $(\mathrm{N}=635) .{ }^{57}$ Among presbyopia patients ( $30 \%$ of the study population), a mean visual function score of 85.1 (95\% CI: 83.1-87.1) and a mean quality of life score of 78.1 (95\% CI: 69.6-75.5) was reported (scores range: $0-100$, with lower scores signifying poorer quality of life) meaning that presbyopia could decrease patients' quality of life by $22 \%$ compared to a person with full health. ${ }^{57}$ Further, patients with uncorrected presbyopia reported functional difficulty in performing daily activities such as reading, writing, threading needles, and using mobile phones.

Holden et al $(2008)^{15}$ conducted a global review of population-based surveys to evaluate the personal and community burdens of uncorrected presbyopia. The authors estimated that approximately $80 \%$ of patients $(410$ of 517 million) ${ }^{15}$ with uncorrected presbyopia had difficulty in performing near-vision related tasks such as reading, writing, threading needles, and using mobile phones. Other studies also reported similar difficulties in near-visionrelated tasks in presbyopic patients (Figure 2). ${ }^{28,60-62}$

Lu et al $(2011)^{36,37}$ conducted a population-based crosssectional survey to evaluate the effect of presbyopia on quality of life in Chinese adults aged $\geq 40$ years $(\mathrm{N}=776) .{ }^{36,37}$ Overall, $69 \%(\mathrm{n}=538)$ of the study population was presbyopic and $31 \%(\mathrm{n}=238)$ had no presbyopia. Reportedly, 50.4\% (120/238) of the adults without presbyopia indicated good or very good overall eyesight, compared to only $24.7 \%$ (133/538) of persons with presbyopia. Over $90 \%$ of those with presbyopia reported some level of difficulty with activities of daily living, whereas more than a third of those without presbyopia had no such difficulties. ${ }^{36,37}$ The odds of reporting any difficulty with

\section{Uncorrected Presbyopia}

\section{Impact}

Difficulty in day-to-day activities ${ }^{28,60,61,62}$

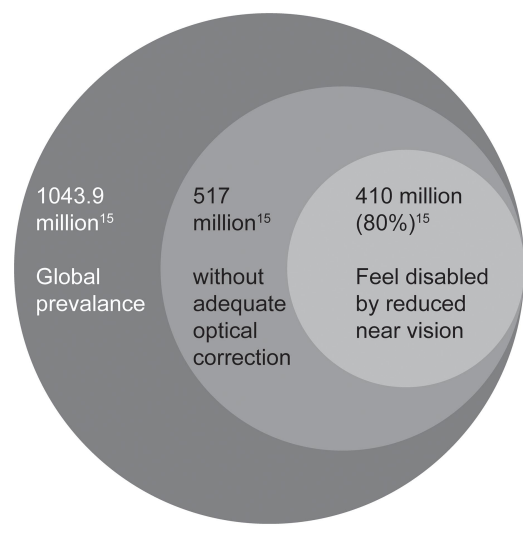

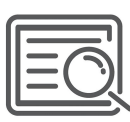

Reading

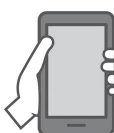

Using mobile phones

Inconvenience ${ }^{60,61}$

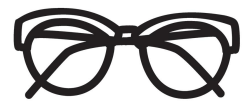

Carrying glasses, swapping glasses handling contact lenses, cleaning glasses, relying on glasses, adjusting to new prescriptions

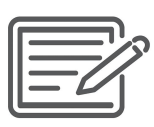

Writing

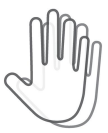

Blurred vision

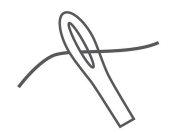

Threading needles

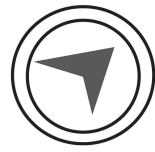

Difficulties

in using navigation

\section{Economic implications $^{60,61}$}
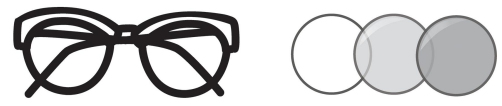

cost of glasses, contact lenses, working ability, career choices

Figure 2 Impact of uncorrected presbyopia on daily activities. Sources: Holden et al, ${ }^{15}$ Kandel et al, ${ }^{60}$ Kandel et al, ${ }^{61}$ Sherwin et al, ${ }^{28}$ and Patel et al. ${ }^{62}$. 
daily tasks remained higher (OR: $2.32 ; p=0.001)$ for presbyopes after adjustment for age, sex, education, and distance vision. Compared with non-presbyopic individuals, presbyopes more often reported diminished accomplishment in terms of household activities, social interaction, and work and leisure time pursuits. Furthermore, $12 \%$ of the presbyopes reported requiring help from others due to a decrease in their visual function. In the same study, $15 \%$ reported a low sense of accomplishment due to impaired vision and $7 \%$ stated feeling ashamed or embarrassed due to poor vision. The study demonstrated the limitations in daily activities imposed by presbyopia and the corresponding impact on the rural population. The impairment was notably linked to vision-specific distress due to a broader social impairment associated with shame and embarrassment of vision deficit in patients.

Patel et al (2006) ${ }^{62}$ conducted a cross-sectional, population-based survey to determine the impact of uncorrected presbyopia on vision-targeted quality of life in rural African presbyopia patients aged $\geq 40$ years $(\mathrm{N}=1,564) .{ }^{62}$ The authors reported that uncorrected presbyopia led to a 2-fold increased difficulty in performing near-vision related tasks and a $>8$-fold increased difficulty in performing very demanding near-vision-related tasks. Increasing age was found to be associated with higher odds of reporting difficulty for near-vision-related tasks. ${ }^{62}$

Kandel et al (2017) ${ }^{60,61}$ conducted qualitative, interviewbased studies in Australia $(\mathrm{N}=48)^{60}$ and Nepal $(\mathrm{N}=101)^{61}$ to explore the impact of refractive errors on patients' quality of life. Thematic analysis performed in both these studies identified six themes related to the quality of life related concerns in people with refractive errors (including presbyopia): worry; difficulty in performing physical, recreational, and day-to-day activities; inconvenience; unwanted ocular and non-ocular sensations; psychosocial well-being; and economic implications. The studies also highlighted inconvenience-related concerns associated with spectacles and contact lens use by patients to correct their refractive errors. ${ }^{60,61}$ Other studies from USA, Iran, and Timor-Leste also demonstrated the burden of presbyopia on patients and the impact on their quality of life due to increased visionrelated disability. ${ }^{58,59,63}$

Utilities represent the strength of individual preferences for different health states, and are an important measure for determining patient's quality of life. ${ }^{64}$ Utility values range between 0 (representing death) and 1 (perfect health), with higher values representing better quality of life with the associated health condition. ${ }^{64}$ In this review, two studies were identified that estimated utility values in presbyopia patients using a patient preference-based, time trade-off methodology. 65,66

Luo et al (2008) interviewed 110 patients (from Pennsylvania Eye Care Center, USA) with spectaclecorrected presbyopia and a best-corrected visual acuity of $20 / 40$ or better in a cross-sectional, patient preference-based, time trade-off utility analysis to derive the health-related utilities with presbyopia. ${ }^{65}$ The authors reported a mean utility of 0.98 (SD $0.086,95 \%$ CI $0.33-1.0$ ) for the total cohort of 110 corrected presbyopic patients. Through a time trade-off experiment, the authors elicited that $10 \%$ of the presbyopia

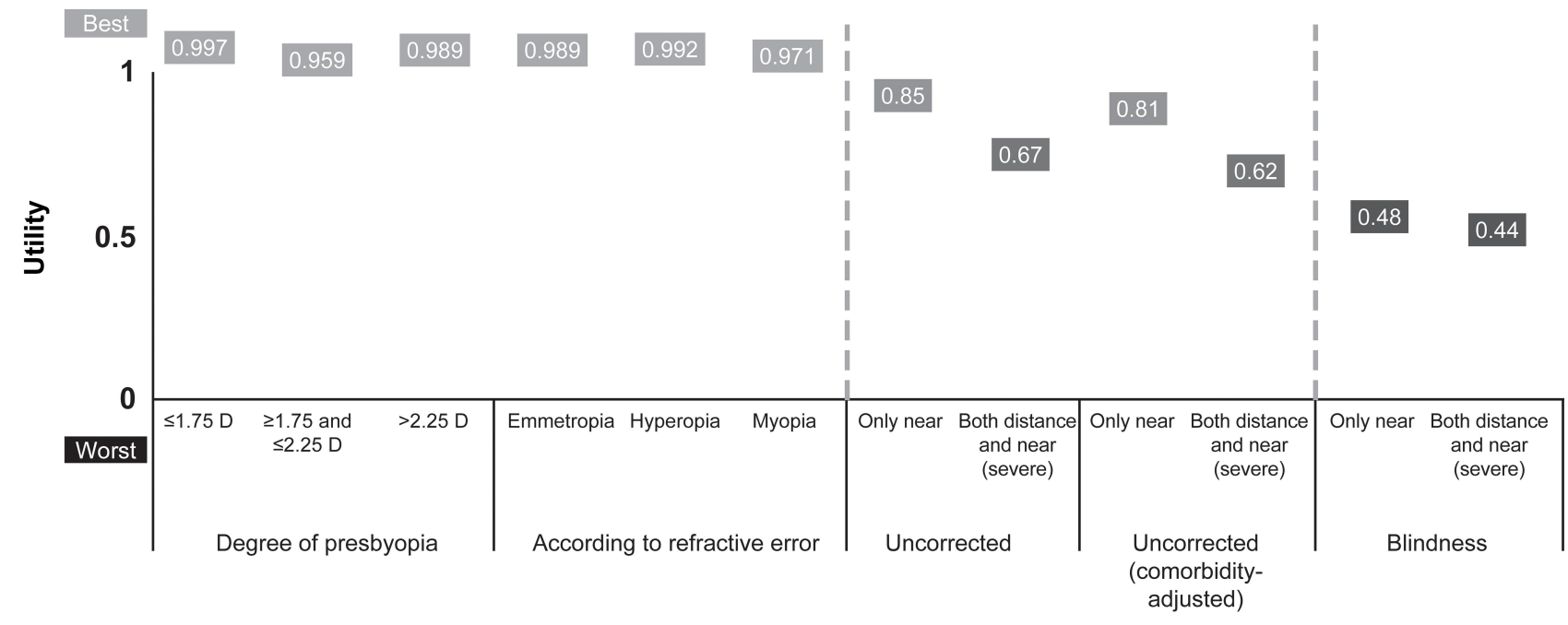

Corrected $^{65}$

Uncorrected ${ }^{66}$

Figure 3 Variation in health-related quality of life scores (utilities) for corrected and uncorrected presbyopia patients. Sources: Luo et al ${ }^{65}$ and Tahhan et al. ${ }^{66}$ 
patients were willing to trade-off $5 \%$, while $\sim 6 \%$ of the presbyopia patients were willing to trade-off $10 \%$ of their remaining lifetime to get rid of presbyopia, which signifies the impact of the condition on patients' quality of life. Corrected patient cohorts in the study were also analyzed according to the degree of presbyopia (Group 1: $\leq 1.75 \mathrm{D}$, Group 2: $\geq 1.75 \mathrm{D}$ and $\leq 2.25 \mathrm{D}$, Group 3: $\geq 2.25 \mathrm{D}$ ), and according to patients' primary refractive error (either emmetropia, myopia or hyperopia). The mean utility values were similar across the groups, implying that correction of presbyopia with varying refractive errors provided similar benefits (Figure 3). ${ }^{65}$

A measurable decrement in QoL due to uncorrected presbyopia, based on considerably low utility values, was observed in the study by Tahhan et al (2013). The authors conducted a cross-sectional study using a standardized, faceto-face time trade-off interview method to determine utilities associated with uncorrected refractive error (including presbyopia) in 341 patients (40-65 years of age) undergoing an eye examination at a university-based eye research clinic in Sydney, Australia. ${ }^{66}$ The authors observed that presbyopia coexisting with far-sight refractive errors was found to be associated with a noticeable reduction in patients' visionrelated QoL (comorbidity-adjusted utility of 0.62 in severe patients to 0.70 in moderate patients) (Figure 3). The utility values for patients with coexisting distance and near vision impairment were significantly worsened compared to patients with distance vision or near vision impairment alone (adjusted and unadjusted, $p<0.01$ ). ${ }^{66}$

\section{Economic Burden}

\section{Productivity Loss Due to Presbyopia}

Frick et al $(2015)^{5}$ conducted an economic modeling study wherein population data from the US Census Bureau was combined with the estimated presbyopia prevalence, age of onset, employment rate, gross domestic product (GDP) per capita in current US dollars, and near-vision impairment disability weights from the GBD 2010 study. Using these data, the authors estimated the global loss of productivity from uncorrected and under-corrected presbyopia in $2011 .^{5}$

Across a total of 244 million working-age presbyopic patients worldwide, aged $<50$ years (both uncorrected and under-corrected), presbyopia was estimated to result in annual productivity losses of US\$ 11.0 billion $(0.016 \%$ of the global GDP). If all those people aged $<65$ years were assumed to be productive, the potential annual productivity losses would increase to US\$ 25.4 billion or $0.037 \%$ of the global GDP (Figure 4). ${ }^{5}$ The authors further estimated that if presbyopia was corrected to the level achieved in Europe ( $96 \%$ correction as per Holden et $\mathrm{al}^{15}$ ) from the current levels (highest, $84 \%$ in North America and lowest, $6 \%$ in Africa, outside of Europe), annual productivity losses could be reduced by US\$10 billion to US\$ 1.4 billion (Figure 4). ${ }^{5}$

\section{Discussion}

The current study was aimed at conducting a systematic literature review of the published evidence on epidemiology and burden of presbyopia (patient and economic burden) using standard methodology.

Presbyopia prevalence in the literature varied between regions with the highest prevalence reported from Latin America, ranging between $54.7 \%$ and $90.0 \%$ in adults $\geq 35$ years. ${ }^{14,15}$ The prevalence of presbyopia was reported in 43 publications however epidemiological data was still missing from key demographics such as Europe and large developing economies such as India and Russia. Future epidemiology studies should focus on these geographies. In addition, we found only one study ${ }^{52}$ which estimated the incidence of

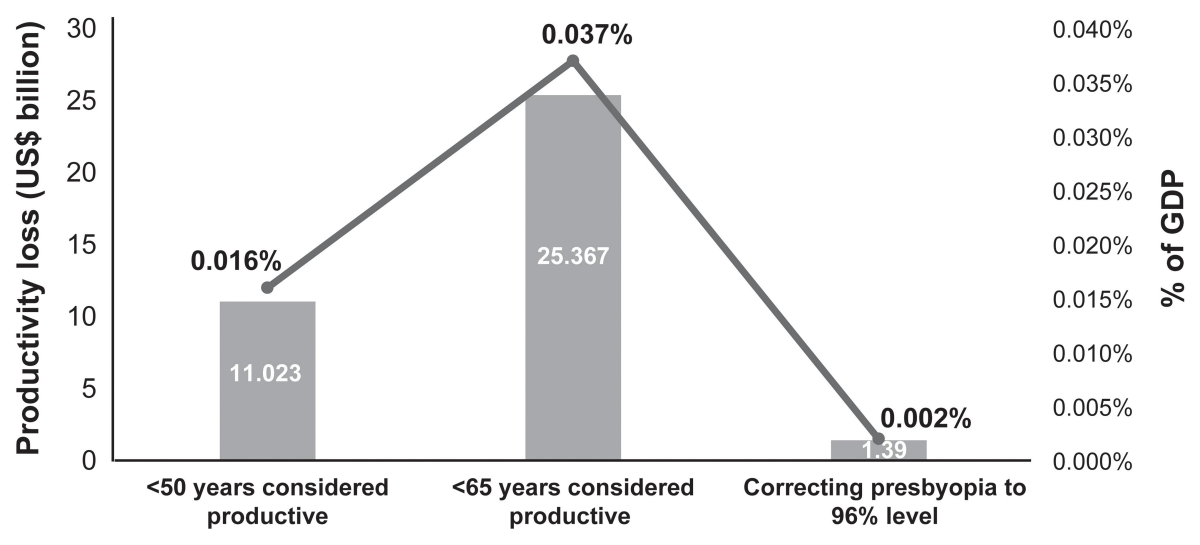

Figure 4 Global productivity loss associated with uncorrected presbyopia. Sources: Frick et al (20I5). ${ }^{5}$. 
presbyopia (study quality assessment $=$ moderate) therefore the current evidence base needs to be further strengthened to better understand the onset of the condition and to inform vision care guidelines and policies. Nine studies which reported presbyopia epidemiology did not specify the definition used for the diagnosis of presbyopia which made it difficult to interpret and contrast findings with other studies. We recommend future studies should consistently provide this information to help readers in interpreting evidence.

Among the identified risk factors that contributed towards presbyopia development, age played a significant role as the odds of developing presbyopia increased by $16 \%$ per year from age 40 to $50 .^{22}$ The odds of developing presbyopia are higher in patients with hyperopia, as uncorrected hyperopes use up part of their residual amplitude in overcoming their hyperopia. ${ }^{35,38,67}$ One study conducted in $\operatorname{Iran}^{38}$ reported that women have a higher prevalence of presbyopia as well as having a greater increase in presbyopia prevalence with increasing age when compared to men. In addition, people of short stature were found to have earlier onset of presbyopia probably because they use shorter working distances which may require greater accommodation. ${ }^{68}$

Nearly half of the presbyopia patients remain uncorrected, especially in the developing countries. ${ }^{15}$ Uncorrected presbyopia was reported to be having a 2-fold increase in difficulty to perform near-vision related tasks and an $>8$-fold increase in difficulty in performing very demanding near-vision related tasks in subjects aged $>40$ years compared to younger subjects aged $<40$ years. ${ }^{62}$ As many as $80 \%$ of the uncorrected presbyopes faced trouble in performing near-vision-related tasks such as reading, writing, threading needles, and using mobile devices which could impact patients' productivity. ${ }^{15}$ Published evidence suggests that up to $12 \%$ patients reportedly required help from others to perform daily tasks which could pose a significant disabilityrelated burden. ${ }^{36,37}$ Uncorrected presbyopia could also impact mental well-being of patients with up to $15 \%$ patients reporting a low sense of accomplishment due to impaired vision, while $7 \%$ of patients stated feeling ashamed or embarrassed due to poor vision. ${ }^{36,37}$

Studies evaluating utility values in uncorrected presbyopia demonstrated a decrease in the overall QoL in presbyopia patients due to impaired vision. ${ }^{65,66}$ The impact of presbyopia on patients' quality of life is evident as $10 \%$ of the presbyopia patients were reportedly willing to trade-off $5 \%$ of their remaining lifetime and $\sim 6 \%$ were willing to trade-off $10 \%$ of remaining life-time to get rid of presbyopia. ${ }^{65}$ These findings show that presbyopia could affect patients' ability to perform activities of daily living which demand near vision and some patients could require caregiver assistance. Presbyopes report having negative impact of the condition on their quality of life. In developing countries, where access to vision care services is limited or not provisioned by healthcare systems, this could lead to patients persisting with uncorrected presbyopia and with reduced quality of life. Moreover, in many developed countries vision care services are outside covered benefits and patients are required either to pay out-ofpocket expenses or buy private vision care insurance which could leave out economically disadvantaged people and make them vulnerable to un-/under-corrected presbyopia and consequentially lead to a decrement in their quality of life.

In this review, only one study was found which reported productivity losses due to uncorrected presbyopia. The global annual productivity losses were estimated to be US\$ 25 billion or $0.037 \%$ of the global GDP in the working-age presbyopic adults ( $\leq 65$ years). ${ }^{5}$ Optimal correction of presbyopia could help in mitigating this productivity loss due to presbyopia. ${ }^{4}$ This area should be further investigated by designing primary research studies across countries to better estimate true local and global economic impact of presbyopia on patients and societies.

To our knowledge, this study is the first comprehensive systematic literature review that has reported on the epidemiology, patient burden, and economic burden associated with presbyopia. We followed the recommended methodology, and used the comprehensive and systematic approach to document the published evidence on presbyopia burden. However, there are some limitations. First, studies published in English language only were included. Second, due to the paucity of evidence, some studies which reported overall disease burden due to refractive errors including presbyopia were included.

\section{Conclusions}

The findings from the current study highlight the patient, societal, and economic burden of presbyopia. More than half of the middleaged to elderly population is affected by presbyopia, with an estimated 1.09 billion worldwide prevalent cases of presbyopia. Patients with presbyopia report difficulty in performing near-vision -related tasks and may require caregivers' help in some situations. 
Un-/under-corrected presbyopia could pose an economic burden for patients by affecting their work productivity when they require demanding use of near vision to perform work-related tasks. With an increasing population and an ageing society, there is a need for greater access to vision care services across the globe for timely screening and optimized correction of presbyopia, especially in the working-age population. Further research is required to understand the epidemiology of presbyopia in Europe and countries with large populations such as India. In addition, new evidence with good quality primary research is required to estimate economic impact of the condition on patients and societies.

\section{Acknowledgments}

The authors would like to thank Raj Kumar Mothe (Novartis Healthcare Pvt. Ltd.) and Prince Rana (Novartis Healthcare Pvt. Ltd.) for literature review support and Lovneet Saini (Novartis Healthcare Pvt. Ltd.) for providing scientific writing support.

\section{Disclosure}

Dr John Berdahl and Dr Chandra Bala received consulting fees from Alcon. Dr Mukesh Dhariwal and Dr Jessie Lemp-Hull are employees of Alcon Vision LLC (the study sponsor); Divyesh Thakker and Shantanu Jawla were employees (at the time of research) of Novartis Healthcare Pvt. Ltd which received consulting fee from Alcon to conduct this study. The authors report no other conflicts of interest related to this work. The abstract of this paper was presented at the 2020 Virtual Annual Meeting of American Society of Cataract and Refractive Surgery (ASCRS) as a free paper presentation. The presentation is available online on the ASCRS website - (https://cos.ascrs.org/home/clinical-education /presbyopia/2020-pod-sps-107-64522-global-prevalencepatient-and-economic-burden-of-presbyopia-a-sys). The abstract of this paper was also presented at the 38th congress of the European Society of Cataract and Refractive Surgery (ESCRS) as a free paper in October 2020. The abstract is available online on the ESCRS website - (https://www.escrs.org/amsterdam2020/pro gramme/free-papers-details.asp?id=36937).

\section{References}

1. Glasser A, Campbell MC. Biometric, optical and physical changes in the isolated human crystalline lens with age in relation to presbyopia. Vision Res. 1999;39(11):1991-2015. doi:10.1016/S0042-6989(98) 00283-1
2. Goertz AD, Stewart WC, Burns WR, Stewart JA, Nelson LA. Review of the impact of presbyopia on quality of life in the developing and developed world. Acta Ophthalmol. 2014;92(6):497-500. doi:10.1111/aos.12308

3. American Optometric Association. Optometric clinical practice guideline care of the patient with presbyopia; 2010. Available from: https://www.aoa.org/documents/optometrists/CPG-17.pdf. Accessed Nov 18, 2019.

4. Reddy PA, Congdon N, MacKenzie G, et al. Effect of providing near glasses on productivity among rural Indian tea workers with presbyopia (PROSPER): a randomised trial. Lancet Glob Health. 2018;6(9): E1019-E1027. doi:10.1016/S2214-109X(18)30329-2

5. Frick KD, Joy SM, Wilson DA, Naidoo KS, Holden BA. The global burden of potential productivity loss from uncorrected presbyopia. Ophthalmology. 2015;122(8):1706-1710. doi:10.1016/j. ophtha.2015.04.014

6. Pew Research Center. Americans 60 and Older are Spending More Time in Front of Their Screens Than a Decade Ago. 2019.

7. Sheppard AL, Wolffsohn JS. Digital eye strain: prevalence, measurement and amelioration. BMJ Open Ophthalmol. 2018;3(1):e000146. doi:10.1136/bmjophth-2018-000146

8. Coles-Brennan C, Sulley A, Young G. Management of digital eye strain. Clin Exp Optom. 2019;102(1):18-29. doi:10.1111/cxo.12798

9. Ong HS, Evans JR, Allan BD. Accommodative intraocular lens versus standard monofocal intraocular lens implantation in cataract surgery. Cochrane Database Syst Rev. 2014;2014(5):CD009667.

10. Higgins J, Green S(eds) Cochrane Handbook for Systematic Reviews of Interventions. The Cochrane Collaboration, 2011.

11. Moher D, Liberati A, Tetzlaff J, Altman DG, Group P. Preferred reporting items for systematic reviews and meta-analyses: the PRISMA statement. J Clin Epidemiol. 2009;62(10):1006-1012. doi:10.1016/j.jclinepi.2009.06.005

12. Centers for Disease Control and Prevention. Principles of epidemiology in public health practice, third edition an introduction to applied epidemiology and biostatistics; 2012. Available from: https://www.cdc.gov/csels/ dsepd/ss1978/lesson3/section2.html. Accessed August 27, 2020.

13. Bourne RRA, Flaxman SR, Braithwaite T, et al. Magnitude, temporal trends, and projections of the global prevalence of blindness and distance and near vision impairment: a systematic review and meta-analysis. Lancet Glob Health. 2017;5(9):e888-e897. doi:10.1016/S2214-109X(17)30293-0

14. Hookway LA, Frazier M, Rivera N, Ramson P, Carballo L, Naidoo K. Population-based study of presbyopia in Nicaragua. Clin Exp Optom. 2016;99(6):559-563. doi:10.1111/cxo.12402

15. Holden BA, Fricke TR, Ho SM, et al. Global vision impairment due to uncorrected presbyopia. Arch Ophthalmol. 2008;126 (12):1731-1739. doi:10.1001/archopht.126.12.1731

16. Mitchell JP, Williams N, Martin R, et al. The Venezuela eye evaluation study. J Natl Med Assoc. 2008;100(4):435-438. doi:10.1016/ S0027-9684(15)31278-5

17. Cunha CC, Berezovsky A, Furtado JM, et al. Presbyopia and ocular conditions causing near vision impairment in older adults from the Brazilian Amazon region. Am J Ophthalmol. 2018;196:72-81. doi:10.1016/j.ajo.2018.08.012

18. Census US. U.S.: Estimated 2010 Prevalence of Presbyopia in Adults Aged 45 or Older; census Figure Applied to Prevalence Number to Calculate Rate Bonilla-Warford N; "What to Do with "New" Presbyopes." Review of Optometry. 2010, p.42.

19. Ajibode HA, Fakolujo VO, Onabolu OO, Jagun O, Ogunlesi TA, Abiodun OA. A community-based prevalence of presbyopia and spectacle coverage in Southwest Nigeria. J West Afr Coll Surg. 2016;6(4):66-82.

20. Kaphle D, Gyawali R, Kandel H, Reading A, Msosa JM. Vision impairment and ocular morbidity in a refugee population in Malawi. Optom Vis Sci. 2016;93(2):188-193. doi:10.1097/OPX.0000000000000775 
21. Patel I, West SK. Presbyopia: prevalence, impact, and interventions. Community Eye Health. 2007;20(63):40-41.

22. Burke AG, Patel I, Munoz B, et al. Population-based study of presbyopia in rural Tanzania. Ophthalmology. 2006;113(5):723-727. doi:10.1016/j.ophtha.2006.01.030

23. Kimani K, Lindfield R, Senyonjo L, Mwaniki A, Schmidt E, Wedrich A. Prevalence and causes of ocular morbidity in Mbeere District, Kenya. Results of a population-based survey. PLoS One. 2013;8(8):e70009. doi:10.1371/journal.pone.0070009

24. Chan VF, Mebrahtu G, Ramson P, Wepo M, Naidoo KS. Prevalence of refractive error and spectacle coverage in Zoba Ma'ekel Eritrea: a rapid assessment of refractive error. Ophthalmic Epidemiol. 2013;20(3):131-137. doi:10.3109/09286586.2013.783082

25 . Laviers $\mathrm{H}$. The prevalence of presbyopia and the feasibility of community distribution of near spectacles in adults in Zanzibar, East Africa. Community Eye Health. 2007;20(64):73.

26. Umar MM, Muhammad N, Alhassan MB. Prevalence of presbyopia and spectacle correction coverage in a rural population of North West Nigeria. Clin Ophthalmol. 2015;9:1195-1201. doi:10.2147/OPTH.S81194

27. Seidu MA, Bekibele CO, Ayorinde OO. Prevalence of presbyopia in a semi-urban population of southwest, Nigeria: a community-based survey. Int Ophthalmol. 2016;36(6):767-773. doi:10.1007/s10792016-0198-3

28. Sherwin JC, Keeffe JE, Kuper H, Islam FM, Muller A, Mathenge W. Functional presbyopia in a rural Kenyan population: the unmet presbyopic need. Clin Exp Ophthalmol. 2008;36(3):245-251. doi:10.1111/j.1442-9071.2008.01711.x

29. Uche JN, Ezegwui IR, Uche E, Onwasigwe EN, Umeh RE, Onwasigwe CN. Prevalence of presbyopia in a rural African community. Rural Remote Health. 2014;14(3):2731.

30. Obajolowo TS, Owoeye J, Adepoju FG. Prevalence and pattern of presbyopia in a rural Nigerian community. $J$ West Afr Coll Surg. 2016;6(3):83-104.

31. Mashayo ER, Chan VF, Ramson P, Chinanayi F, Naidoo KS. Prevalence of refractive error, presbyopia and spectacle coverage in Kahama District, Tanzania: a rapid assessment of refractive error. Clin Exp Optom. 2015;98(1):58-64. doi:10.1111/cxo.12207

32. Naidoo KS, Jaggernath J, Martin C, et al. Prevalence of presbyopia and spectacle coverage in an African population in Durban, South Africa. Optom Vis Sci. 2013;90(12):1424-1429. doi:10.1097/ OPX.0000000000000096

33. Abdullah AS, Jadoon MZ, Akram M, et al. Prevalence of uncorrected refractive errors in adults aged 30 years and above in a rural population in Pakistan. J Ayub Med Coll Abbottabad. 2015;27(1):8-12.

34. Muhit M, Minto H, Parvin A, et al. Prevalence of refractive error, presbyopia, and unmet need of spectacle coverage in a northern district of Bangladesh: rapid assessment of refractive error study. Ophthalmic Epidemiol. 2018;25(2):126-132. doi:10.1080/ 09286586.2017.1370119

35. Nirmalan PK, Krishnaiah S, Shamanna BR, Rao GN, Thomas R. A population-based assessment of presbyopia in the state of Andhra Pradesh, south India: the Andhra Pradesh eye disease study. Invest Ophthalmol Vis Sci. 2006;47(6):2324-2328. doi:10.1167/iovs.05-1192

36. Lu Q, Congdon N, He X, Murthy GV, Yang A, He W. Quality of life and near vision impairment due to functional presbyopia among rural Chinese adults. Invest Ophthalmol Vis Sci. 2011;52(7):4118-4123. doi:10.1167/iovs.10-6353

37. Lu Q, He W, Murthy GV, et al. Presbyopia and near-vision impairment in rural northern China. Invest Ophthalmol Vis Sci. 2011;52 (5):2300-2305. doi:10.1167/iovs.10-6569

38. Hashemi H, Khabazkhoob M, Jafarzadehpur E, et al. Populationbased study of presbyopia in Shahroud, Iran. Clin Exp Ophthalmol. 2012;40(9):863-868. doi:10.1111/j.1442-9071.2012.02799.x
39. Marmamula S, Keeffe JE, Raman U, Rao GN. Population-based cross-sectional study of barriers to utilisation of refraction services in South India: rapid assessment of refractive errors (RARE) study. BMJ Open. 2011;1(1):e000172. doi:10.1136/bmjopen-2011-000172

40. Marmamula S, Keeffe JE, Rao GN. Uncorrected refractive errors, presbyopia and spectacle coverage: results from a rapid assessment of refractive error survey. Ophthalmic Epidemiol. 2009;16 (5):269-274.

41. Marmamula S, Khanna RC, Kunuku E, Rao GN. Near visual impairment and spectacle coverage in Telangana, India. Clin Exp Ophthalmol. 2017;45(6):568-574. doi:10.1111/ceo.12943

42. Marmamula S, Khanna RC, Narsaiah S, Shekhar K, Rao GN. Prevalence of spectacles use in Andhra Pradesh, India: rapid assessment of visual impairment project. Clin Exp Ophthalmol. 2014;42 (3):227-234. doi:10.1111/ceo.12160

43. Marmamula S, Madala SR, Rao GN. Rapid assessment of visual impairment (RAVI) in marine fishing communities in South Indiastudy protocol and main findings. BMC Ophthalmol. 2011;11(1):26. doi:10.1186/1471-2415-11-26

44. Marmamula S, Madala SR, Rao GN. Prevalence of uncorrected refractive errors, presbyopia and spectacle coverage in marine fishing communities in South India: rapid assessment of visual impairment (RAVI) project. Ophthalmic Physiol Opt. 2012;32(2):149-155. doi:10.1111/j.1475-1313.2012.00893.x

45. Marmamula S, Narsaiah S, Shekhar K, Khanna RC. Presbyopia, spectacles use and spectacle correction coverage for near vision among cloth weaving communities in Prakasam district in South India. Ophthalmic Physiol Opt. 2013;33(5):597-603. doi:10.1111/ opo. 12079

46. Marmamula S, Ravuri LV, Boon MY, Khanna RC. Spectacle coverage and spectacles use among elderly population in residential care in the south Indian state of Andhra Pradesh. Biomed Res Int. 2013;2013:183502. doi:10.1155/2013/183502

47. Ramke J, Brian G, Naduvilath T. Refractive error and presbyopia in timor-leste: the impact of 5 years of a national spectacle program. Invest Ophthalmol Vis Sci. 2012;53(1):434-439. doi:10.1167/iovs.118161

48. Ramke J, Du Toit R, Palagyi A, Brian G, Naduvilath T. Correction of refractive error and presbyopia in Timor-Leste. $\mathrm{Br} J$ Ophthalmol. 2007;91(7):860-866. doi:10.1136/bjo.2006.110502

49. Brian G, Pearce MG, Ramke J. Refractive error and presbyopia among adults in Fiji. Ophthalmic Epidemiol. 2011;18(2):75-82.

50. Cheng F, Shan L, Song W, Fan P, Yuan H. Distance- and near-visual impairment in rural Chinese adults in Kailu, Inner Mongolia. Acta Ophthalmol. 2016;94(4):407-413. doi:10.1111/aos.12808

51. Landers J, Henderson T, Craig J. Central Australian ocular health study: design and baseline description of participants. Clin Exp Ophthalmol. 2010;38(4):375-380. doi:10.1111/j.14429071.2010.02255.x

52. Han X, Lee PY, Keel S, He M. Prevalence and incidence of presbyopia in urban Southern China. Br J Ophthalmol. 2018;102 (11):1538-1542. doi:10.1136/bjophthalmol-2017-311073

53. Shrote VK, Thakr SS, Lanjewar AG, Brahmapurkar KP, Khakse GM. Ocular morbid conditions in the rural area of central India. Int J Collab Res Intern Med Public Health. 2012;4(9):1692-1702.

54. Hussain A, Awan H, Khan MD. Prevalence of non-vision-impairing conditions in a village in Chakwal district, Punjab, Pakistan. Ophthalmic Epidemiol. 2004;11(5):413-426. doi:10.1080/ 09286580490888799

55. Fricke TR, Tahhan N, Resnikoff S, et al. Global prevalence of presbyopia and vision impairment from uncorrected presbyopia: systematic review, meta-analysis, and modelling. Ophthalmology. 2018;125(10):1492-1499. doi:10.1016/j.ophtha.2018.04.013 
56. Mancil GL, Bailey IL, Brookman KE, et al. Optometric Clinical Practice Guideline: Care of the Patients with Presbyopia. St. Louis, MO: American Optometric Association; 2011.

57. Muhammad N, Alhassan MB, Umar MM. Visual function and vision-related quality of life in presbyopic adult population of Northwestern Nigeria. Niger Med J. 2015;56(5):317-322. doi:10.4103/0300-1652.170379

58. McDonnell PJ, Lee P, Spritzer K, Lindblad AS, Hays RD. Associations of presbyopia with vision-targeted health-related quality of life. Arch Ophthalmol. 2003;121(11):1577-1581. doi:10.1001/ archopht.121.11.1577

59. Du Toit R, Palagyi A, Ramke J, Brian G, Lamoureux EL. The impact of reduced distance and near vision on the quality of life of adults in Timor-Leste. Ophthalmology. 2010;117(12):2308-2314. doi:10.1016/ j.ophtha.2010.03.041

60. Kandel H, Khadka J, Goggin M, Pesudovs K. Impact of refractive error on quality of life: a qualitative study. Clin Exp Ophthalmol. 2017;45(7):677-688. doi:10.1111/ceo.12954

61. Kandel H, Khadka J, Shrestha MK, et al. Uncorrected and corrected refractive error experiences of Nepalese adults: a qualitative study. Ophthalmic Epidemiol. 2018;25(2):147-161. doi:10.1080/ 09286586.2017.1376338

62. Patel I, Munoz B, Burke AG, et al. Impact of presbyopia on quality of life in a rural African setting. Ophthalmology. 2006;113 (5):728-734. doi:10.1016/j.ophtha.2006.01.028
63. Hatef E, Mohammadi SF, Alinia C, et al. National burden of eye diseases in Iran, 1990-2010; findings from the global burden of diseases study 2010. Middle East Afr J Ophthalmol. 2016;23 (1):89-95. doi:10.4103/0974-9233.171781

64. Araujo CDM, Veiga DF, Hochman B, Abla LEF, Novo NF, Ferreira LM. Health economics and health preference concepts to orthopedics practitioners. Acta Ortop Bras. 2014;22(2):102-105. doi:10.1590/1413-78522014220200456

65. Luo BP, Brown GC, Luo SC, Brown MM. The quality of life associated with presbyopia. Am J Ophthalmol. 2008;145 (4):618-622. doi:10.1016/j.ajo.2007.12.011

66. Tahhan N, Papas E, Fricke TR, Frick KD, Holden BA. Utility and uncorrected refractive error. Ophthalmology. 2013;120 (9):1736-1744. doi:10.1016/j.ophtha.2013.02.014

67. Leat SJ. To prescribe or not to prescribe? Guidelines for spectacle prescribing in infants and children. Clin Exp Optom. 2011;94 (6):514-527. doi:10.1111/j.1444-0938.2011.00600.x

68. Priyambada S. Premature presbyopia and its risk factors - a hospital based study. Int J Contemp Med Res. 2019;6(3):C1-C4.

69. McDonnell PJ, Lee P, Spritzer K, et al. Associations of presbyopia with vision-targeted health-related quality of life. Evid Based Eye Care. 2004;5(2):100-101. doi:10.1097/00132578-200404000-00020
Clinical Ophthalmology

\section{Publish your work in this journal}

Clinical Ophthalmology is an international, peer-reviewed journal covering all subspecialties within ophthalmology. Key topics include: Optometry; Visual science; Pharmacology and drug therapy in eye diseases; Basic Sciences; Primary and Secondary eye care; Patient Safety and Quality of Care Improvements. This journal is indexed on PubMed

\section{Dovepress}

Central and CAS, and is the official journal of The Society of Clinical Ophthalmology (SCO). The manuscript management system is completely online and includes a very quick and fair peer-review system, which is all easy to use. Visit http://www.dovepress.com/ testimonials.php to read real quotes from published authors. 